\title{
ASSESSMENT OF SERUM INTERLEUKIN-10 LEVEL IN CHRONIC HEPATITIS C PATIENTS TREATED WITH PEGYLATED INTERFERON AND RIBAVIRIN
}

\author{
*Abd al aziz S. Z., "Hannan A. Soliman, ${ }^{* *}$ Abdel raheim S. R., \\ ** Okasha A. M. and ${ }^{* * *}$ Nilly Helmy Abdalla \\ *Department of chemistry, Faculty of Science, Beni-Suef University, \\ ** Department of Biochemistry, Faculty of Medicine, Minia University, Egypt \\ ${ }^{* * *}$ Department of Internal Medicine, Faculty of Medicine, Beni-Suef University
}

\begin{abstract}
Hepatitis $C$ virus (HCV) infection is a major health problem. Egypt has the highest prevalence worldwide. Currently, combined pegylated interferon and ribavirin therapy is the standard treatment but the outcome is not satisfactory. The present study aimed To assess the possible association of serum IL-10 level, SOD activity in erythrocyte lysate and plasma MDA level and response to combined interferon $\alpha-$ $2 a$ and ribavirin therapy in chronic HCV infection.

In (Group I) who were not responded to pegylated interferon and rebavirin combination therapy we found the level of serum IL-10 and plasma MDA still high while antioxidant enzyme SOD activity reduced. While in (Group II) who responded to pegylated interferon and rebavirin combination therapy a circulating serum IL-10 and plasma MDA levels reduced but erythrocyte antioxidant enzyme SOD activity increased.
\end{abstract}

Key Words: chronic hepatitis C, IL-10, pegylated interferon. 


\section{INTRODUCTION}

Hepatitis $\mathrm{C}$ virus (HCV) is a meticulous factor of liver disease and one of the most important health issues worldwide (Appel et al., 2008). Hepatitis $\mathrm{C}$ has approximately 175 million global disease burden which represent almost $3 \%$ of the whole population in the world, each year 3 to 4 million new patients with HCV are diagnosed. HCV remains endemic in many countries of the world (Simmonds 2004).

Human liver has complex sets of antioxidants (micronutrients, vitamins, and enzymes) that prevent oxidative damage of the life-saving hepatic cell components (Muriel, 2009).

Lipid peroxidation caused by free radicals being one of the most important mechanisms. Increase of lipid peroxidation could possibly play a role in the complication of cardiovascular disease, chronic pulmonary disease, cataract, cancer (Guerra and Ann 2001).

A free radical is an atom or molecule that has one or more unpaired electrons, they are two types; a reactive oxygen species (ROS), such as super oxide anion radical $\left(\mathrm{O}^{-} 2\right)^{-}$, hydrogen peroxide $(\mathrm{H} 2 \mathrm{O} 2)$, hydroxyl radical $\left(\mathrm{OH}^{-}\right)$and singlet oxygen $\left(\mathrm{O}_{2}\right)(\boldsymbol{H}$. A. Boushey et al ., 1980). And reactive nitrogen species (RNS), such as nitrous oxide $\left(\mathrm{NO}^{-}\right)$, nitric oxide $\left(\mathrm{NO}^{-}\right)$, peroxynitrite $\left(\mathrm{OONO}^{-}\right)$. Because ROS are so reactive, they can inflict considerable damage on living cells if formed in significant amounts. These damage results primarily form enzyme inactivation, polysaccharide depolimerization, DNA breakage and membrane destruction (T. Fouad, http: www, 2005). 
Normally, the ROS are generated in small physiological amounts but when hepatic intracellular ROS production exceeds the antioxidant defense, oxidative damage of intracellular content, breakage of DNA strands, and peroxidation of polyunsaturated fatty acids in hepatocyte membrane occur (Muriel P, 2009).

LPO is caused by free radicals leading to oxidative destruction of polyunsaturated fatty acids constitutive of cellular membranes. Their destruction leads to the production of toxic and reactive aldehyde metabolites such as MDA and HNE. These highly cytotoxic metabolites, produced in relatively large amounts, can diffuse from their site of origin to attack distant targets and form covalent bonds with various molecules. Therefore, recognition of LPO is of interest, as the deleterious effects of this process, including fibrogenesis, might be prevented by administration of scavenging systems or antioxidants (Levent Get al., 2006).

Most previous studies investigating lipid peroxidation dealt with blood and tissue extracts by indirect quantitative methods; the thiobarbituric acid test has been the most commonly applied. Using this procedure, an increase in MDA was observed in the serum, and the liver of patients with chronic hepatitis $\mathrm{C}$. Recently, specific antibodies against MDA and HNE adducts have been raised (Paradis $V$ et al., 1997).

Oxidative stress occurs when this balance is disrupted by extreme production of reactive oxygen species and by insufficient anti oxidative defenses, including superoxide dismutase (SOD), catalase (CAT), vitamins (C,E), ß-carotene, uric acid, glutathion $(\mathrm{GSH})$, and trace elements such as zinc ( $\mathrm{Zn})$, selenium (Se), magnesium $(\mathrm{Mg})$, cupper

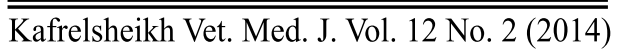


$(\mathrm{Cu})$, iron $(\mathrm{Fe})$, which are Co factor for many biochemical reactions (Parola and Robino 2001).

Oxidative stress has been detected in almost all clinical and experimental conditions of the chronic liver diseases (Parola M and Robino G, 2001).

It has been suggested that $\mathrm{HCV}$ may cause oxidative stress in infected cell. Several lines of evidence support this contention, including the existence of activated glutathione turnover, the presence of increased levels of lipid peroxidation products and augmented iron stores in the liver, and the finding of diminished reduced glutathione values in peripheral blood mononuclear cells and erythrocytes (Larrea $\boldsymbol{E}$ et al., 1998).

Superoxide dismutase protects a cell from toxic effect of superoxide radical as it catalyzes the dismutation reaction of the radical and it also prevents of hydroxyl radical (Andrzejak et al., 1995).

Interleukin-10 (IL-10) is an immunoregulatory cytokine mainly produced by Th2 cells, which inhibits MHC class II expression on monocytes and macrophages and limits the production of proinflammatory cytokines including IL-1, IL-2, IL-6, TNF- $\alpha$, and IFN- $\gamma$. IL-10 can further limit $\mathrm{T}$ cells activation and differentiation, leading to suppression of proinflammatory responses in tissues (Couper et al., 2008).

Therefore, the physiological role of IL-10 during infectious diseases is likely to reduce tissue damage resulting from the unfavorable 
and excessive effects of inflammation. However, an inappropriate production of IL-10 during a virulent infection may compromise the effectiveness of the immune system, allowing fulminant or persistent infection. Other authors have previously investigated IL-10 in subjects with chronic liver disease, including hepatitis C. Most of the authors found an increase of circulating IL-10, but values similar to healthy controls both in subjects with asymptomatic HCV infection and patients with chronic hepatitis have also been described (Inglot M et al., 2008).

This molecule can attenuate the inflammatory response and deregulate cytokine production and $\mathrm{T}$ cell proliferation. Because of its immunoregulatory action, it has been postulated that inadequate levels of IL-10 can determine long-term escape of pathogens from immune control and give rise to persistent infections (Couper KN et al., 2008).

Interestingly, a reduction of circulating IL-10 levels, reflecting the decrease of transaminases in patients treated with interferon or interferon plus ribavirin, especially in responder subjects. Experimental studies conducted on animal models showed that a IL-10 blockade strategy is capable of ameliorating the outcome of chronic viral infection (Brooks et al., 2006).

Hence this study aimed to assess the possible association of serum IL-10 level, erythrocyte lysate SOD and plasma MDA levels and response to combined interferon $\alpha-2 \mathrm{a}$ and ribavirin therapy in chronic $\mathrm{HCV}$ infection. 


\section{MATERIALS AND METHODS}

A total of 60 cases were enrolled in the study from the inpatient of the Interferon unit in One day surgeries hospital - Minia. Patients age range between 40 and 60 all are males divided in three groups:

Group (I): Twenty patients have been infected with HCV and have been treated with pegylated interferon and ribavirin combination therapy but not responded to treatment after 12 weeks. The patients after treatment still have high activity of ALTand AST and positive PCR for HCV RNA.

Group (II): Twenty patients with chronic hepatitis C infection were selected from patients who were positive HCV antibodies for more than 6 months and were showing high ALT and AST activities before treatment with pegylated interferon and ribavirin combination therapy and responded to treatment after 24 to 48 weeks by showing normal value of ALT and AST and negative PCR for HCV RNA.

Group (III): Twenty healthy, individuals served as control group.

The selected patients' of group I and group II received interferon alfa-2a as vials each 1.2/ vial /week containing 160 mg peg Hansenuladerived liquid interferon (Swan, T 2006).

Ribavirin dose is $800 \mathrm{mg}$ to $1200 \mathrm{mg}$ according to body weight (as shown in the table) administrated orally in two divided doses daily. Ribavirin is taken with food because its absorption increases when taken with a meal. 
Table (1) : Ribavirin-dosing recommendations Snell NJ (2001).

\begin{tabular}{||c||c||}
\hline Genotype & Ribavirin Dose \\
\hline \hline Genotype 1 & $<75 \mathrm{~kg} 1000 \mathrm{mg}$ \\
\hline Genotype 4 & $>75 \mathrm{~kg} 1200 \mathrm{mg}$ \\
\hline
\end{tabular}

\section{Laboratory Investigations:}

5 millilitres of blood samples were collected from all cases from the vein above elbow.

$2 \mathrm{ml}$ of blood samples were collected to prepare erythrocyte lysate for the assay of SOD using colourmetric method by Bio-diagnostic assay kit (Egypt) according to the procedure of Nishikimi et al., 1972.

\section{Preparation of erythrocyte lysate :}

$0.5 \mathrm{ml}$ of heparinized blood centrifuged for 10 minutes at $4000 \mathrm{rpm}$ and then plasma was aspirated off then erythrocytes washed four times with $3 \mathrm{ml}$ of $0.9 \% \mathrm{NaCl}$ solution centrifuged for 10 minutes at $4000 \mathrm{rpm}$ after each wash .The washed centrifuged erythrocytes made up to $2.0 \mathrm{ml}$ with cold redistilled water, mixed and left to stand for 15 minutes.

Two ml of blood samples were collected from all cases and allowed to clot in a clean dry tube at room temperature, centrifuged at 2000 rpm for 10 minutes, and serum was separated and stored at $-80 \mathrm{C}$ for the assay of :

- AST and ALT activities using colorimetric method according to the procedure of (Reitman et al 1957, Schmidt et al 1963). 
- Determination of IL-10 serum level was done using RayBio® Human IL-10 ELISA Kit Protocol (Cat\#: ELH-IL10-001) www. raybiotech.com (RayBiotech, Inc.USA) (de Waal-Malefyt et al 1992, Howard and O'Garra 1992, Hsu et al 1990, Fiorentino et al 1991, Kreft B et al 1992).

One $\mathrm{ml}$ of blood was delivered into a tube containing $100 \mathrm{ml} \mathrm{Na}$ citrate and centrifuged at $3000 \mathrm{rpm}$ for 10 minutes. Plasma was separated and stored at $-80 \mathrm{C}$ for the assay of MDA according to the procedure of (Ohkawa et al 1979).

PCR was done for all the enrolled patients to confirm responders and non responders to pegylated interferon alfa-2a and ribavirin combination therapy (patient's profile in Interferon unit in One day surgeries hospital - Minia).

\section{Statistical analysis:}

Statistical analyses were performed using the SPSS version 16. Differences in the mean of continuous variables was analyzed using parametric test (independent sample T.test). Bivariate correlation was used to assess the significance of correlation between the numerical variables.

Data is presented as Mean $\pm \mathrm{SD}$, values are not significant if more than 0.05 , values are significant if less than 0.05 , values are highly significant if less than 0.01 . 


\section{RESULTS}

The results obtained show no significant difference between non responders (group I) and responders (group II) to interferon and ribavirin combination therapy as regard to demographic data as shown in (table 2).

The results obtained show that there is no significant difference between responders (group II) to interferon and ribavirin combination therapy before and after treatment as regard to weight and BMI as shown in (table 3).

The results obtained show that there is no significant difference between non responders (group I) to interferon and ribavirin combination therapy before and after treatment as regard to weight and BMI as shown in (table 4).

The results obtained show that there is no significant difference in ALT, AST, SOD, MDA and IL-10 between non responders (group I) and responders (group II) to interferon and ribavirin combination therapy before treatment as shown in (table 5).

The results obtained also show that high significant decrease in ALT, AST, SOD, MDA, and IL-10 at $\mathrm{P}$ value $<0.001$ in responders (group II) than non responders (group I) after treatment as shown in (table 6).

The results obtained also show there is no significant difference in ALT, AST, SOD, MDA and IL-10 in non responders (group I) before and after treatment as regarding to laboratory data as shown in (table 7).

The results obtained also showed that when we compare between responders (group II) to interferon and ribavirin combination therapy before and after treatment as regarding to laboratory data we find that

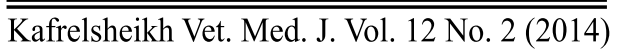


there is a high significant decrease in ALT, AST, MDA and IL-10 at P value $<0.001$, and significant increase of SOD after treatment at $\mathrm{P}$ value $<0.001$ as shown in (table 8 ).

The results show that high significant increase in ALT, SOD and IL-10 in responders (group II) than control (group III) at P value $<0.001$ while there is a no significant difference in MDA as shown in (table 9).

The results also showed that there are a high significant increase in ALT, AST, SOD, MDA and IL-10 at P value $<0.001$ in non responders (group I) after treatment than control (group III) as shown in (table 10).

The results show that high significant increase in ALT, AST, MDA and IL-10 at $\mathrm{P}$ value $<0.001$ in responders (group II) before treatment than control (group III) and significant decrease in SOD in responders group at $\mathrm{P}$ value $<0.001$ as shown in (table 11).

The results obtained also showed that when we compare between control (group III) and non responders (group I) to interferon and ribavirin combination therapy before treatment as regarding to laboratory data we find that there is a high significant increase in ALT, AST, MDA,SOD and IL-10 in non responders group at $\mathrm{P}$ value $<0.001$ as shown in (table 12).

Table (2): Comparison between responders (group II) and non responders (group I) as regard to demographic data.

\begin{tabular}{|c|c|c|c|}
\hline & $\begin{array}{c}\text { Responders (group II) } \\
\text { (No. 20) }\end{array}$ & $\begin{array}{c}\text { Non responders (group I) } \\
(\text { No. 20) }\end{array}$ & p-value \\
\hline Age & $35.8 \pm 7.4$ & $37.3 \pm 7.6$ & 0.5 \\
\hline Height $(\mathrm{cm})$ & $172.6 \pm 8.9$ & $169.5 \pm 11.6$ & 0.3 \\
\hline Weight (before treatment) & $77.2 \pm 9.8$ & $72.4 \pm 9.5$ & 0.1 \\
\hline Weight (after treatment) & $73.4 \pm 9.3$ & $69.3 \pm 9.3$ & 0.1 \\
\hline BMI (before treatment) & $26.2 \pm 4.5$ & $25.5 \pm 4.6$ & 0.6 \\
\hline BMI (after treatment) & $24.9 \pm 4.4$ & $24.4 \pm 4.5$ & 0.7 \\
\hline
\end{tabular}

Kafrelsheikh Vet. Med. J. Vol. 12 No. 2 (2014) 
Assessment Of Serum Interleukin-10 Level In Chronic ...

Table (3): Comparison between responders (group II) before and after treatment responders as regard weight and BMI.

\begin{tabular}{|c|c|c|c|}
\hline & $\begin{array}{c}\text { Responders (before treatment) } \\
\text { (No. 20) }\end{array}$ & $\begin{array}{c}\text { Responders (after treatment) } \\
\text { (No. 20) }\end{array}$ & p-value \\
\hline Weight & $77.2 \pm 9.8$ & $73.4 \pm 9.3$ & 0.3 \\
\hline BMI & $26.2 \pm 4.5$ & $24.9 \pm 4.4$ & 0.2 \\
\hline
\end{tabular}

Table (4): Comparison between non responders (group I) before and after treatment as regard weight and BMI.

\begin{tabular}{|c|c|c|c|}
\hline & $\begin{array}{c}\text { Non responders } \\
\text { (before treatment) (No. 20) }\end{array}$ & $\begin{array}{c}\text { Non responders } \\
\text { (after treatment) (No. 20) }\end{array}$ & p-value \\
\hline Weight & $72.4 \pm 9.5$ & $69.3 \pm 9.3$ & 0.4 \\
\hline BMI & $25.5 \pm 4.6$ & $24.4 \pm 4.5$ & 0.3 \\
\hline
\end{tabular}

Table (5): Comparison between responders (group II) and non responders (group I) before treatment as regarding laboratory data.

\begin{tabular}{|c|c|c|c|}
\hline & P-value & $\begin{array}{c}\text { Responder (group II) } \\
\text { No }=\mathbf{2 0}\end{array}$ & $\begin{array}{c}\text { Non responder (group I) } \\
\text { No }=\mathbf{2 0}\end{array}$ \\
\hline ALT U/L & 0.06 & $89.9 \pm 2.8$ & $91.8 \pm 3.6$ \\
\hline AST U/L & 0.3 & $83.3 \pm 3.8$ & $82.2 \pm 3.2$ \\
\hline SOD U/gm Hb & 0.3 & $1109.2 \pm 2.6$ & $1108.3 \pm 2.8$ \\
\hline MDA nmol / mL & 0.3 & $11.02 \pm 1.9$ & $11.7 \pm 2.6$ \\
\hline IL10 pg/mL & 0.07 & $42.9 \pm 3.4$ & $44.9 \pm 3.6$ \\
\hline
\end{tabular}

Table (6): Comparison between responders (group II) and non responders (group I) after treatment as regarding laboratory data.

\begin{tabular}{||c||c||c||c||}
\hline \multicolumn{1}{|c||}{} & P-value & $\begin{array}{c}\text { Responder (group II) } \\
\text { No }=\mathbf{2 0}\end{array}$ & $\begin{array}{c}\text { Non responder (group I) } \\
\text { No = 20 }\end{array}$ \\
\hline \hline ALT U/L & $<0.001 *$ & $24.1 \pm 2.2$ & $88.9 \pm 2.3$ \\
\hline AST U/L & $<0.001 *$ & $31.2 \pm 2.02$ & $81.3 \pm 2.7$ \\
\cline { 2 - 4 } & $<0.001 *$ & $1993 \pm 3.2$ & $1105.1 \pm 2.3$ \\
\hline SOD U/gm Hb & $<0.001 *$ & $7.2 \pm 1.4$ & $11.5 \pm 1.9$ \\
\hline MDA nmol / mL & $<0.001 *$ & $36.7 \pm 2.8$ & $43.6 \pm 3$ \\
\hline IL10 $\mathrm{pg} / \mathrm{mL}$ & & & \\
\cline { 2 - 4 } & & &
\end{tabular}

* highly significant

$\overline{\text { Kafrelsheikh Vet. Med. J. Vol. } 12 \text { No. } 2 \text { (2014) }}$ 
Abd al aziz S. Z. et., al.

Table (7): Comparison between non responders (group I) before and after treatment as regarding laboratory data.

\begin{tabular}{|c|c|c|c|}
\hline & $\begin{array}{c}\text { Before treatment } \\
\text { No }=\mathbf{2 0}\end{array}$ & $\begin{array}{c}\text { After treatment } \\
\text { No }=\mathbf{2 0}\end{array}$ & P-value \\
\hline ALT U/L & $91.8 \pm 3.6$ & $88.9 \pm 2.2$ & 0.3 \\
\hline AST U/L & $82.1 \pm 3.2$ & $81.2 \pm 2.7$ & 0.3 \\
\hline SOD U/gm Hb & $1108.3 \pm 2.8$ & $1105.1 \pm 2.3$ & 0.2 \\
\hline MDA nmol /mL & $11.7 \pm 2.6$ & $11.5 \pm 1.9$ & 0.8 \\
\hline IL10 pg/mL & $44.9 \pm 3.6$ & $43.6 \pm 3$ & 0.1 \\
\hline
\end{tabular}

Table (8): Comparison between responders(group II)before and after treatment as regarding laboratory data.

\begin{tabular}{|c|c|c|c|}
\hline & $\begin{array}{c}\text { Before treatment } \\
\text { No }=\mathbf{2 0}\end{array}$ & $\begin{array}{c}\text { After treatment } \\
\text { No }=20\end{array}$ & P-value \\
\hline ALTU/L & $89.8 \pm 2.8$ & $24.1 \pm 2.2$ & $<0.001 *$ \\
\hline AST U/L & $83.3 \pm 3.8$ & $31.2 \pm 2$ & $<0.001 *$ \\
\hline SOD U/gm Hb & $1109.2 \pm 2.6$ & $1992.9 \pm 3.2$ & $<0.001 *$ \\
\hline MDA nmol $/ \mathrm{mL}$ & $11 \pm 1.9$ & $7.2 \pm 1.4$ & $<0.001 *$ \\
\hline IL10 pg/mL & $42.9 \pm 3.4$ & $36.7 \pm 2.8$ & $<0.001 *$ \\
\hline
\end{tabular}

* highly significant

Table (9): Comparison between the control (group III) and responders (group II) after treatment as regarding laboratory data.

\begin{tabular}{|c|c|c|c|}
\hline & $\begin{array}{c}\text { Control (group III) } \\
\text { No }=\mathbf{2 0}\end{array}$ & $\begin{array}{c}\text { Responders (group II) } \\
\text { No }=\mathbf{2 0}\end{array}$ & P-value \\
\hline ALT U/L & $21.6 \pm 2.7$ & $24.1 \pm 2.2$ & $0.002 *$ \\
\hline AST U/L & $29.1 \pm 2.6$ & $31.2 \pm 2$ & 0.01 \\
\hline SOD U/gm Hb & $1999 \pm 3.4$ & $1992.9 \pm 3.2$ & $<0.001^{*}$ \\
\hline MDA nmol /mL & $6.9 \pm 0.8$ & $7.2 \pm 1.4$ & 0.3 \\
\hline IL10 pg/mL & $33.4 \pm 2.5$ & $36.7 \pm 2.8$ & $<0.001 *$ \\
\hline
\end{tabular}

* highly significant

$\overline{\text { Kafrelsheikh Vet. Med. J. Vol. } 12 \text { No. } 2 \text { (2014) }}$ 
Assessment Of Serum Interleukin-10 Level In Chronic ...

Table (10): Comparison between the control (group III) and non responders (group I) after treatment as regarding laboratory data.

\begin{tabular}{|c|c|c|c|}
\hline & $\begin{array}{c}\text { Control (group III) } \\
\text { No }=\mathbf{2 0}\end{array}$ & $\begin{array}{c}\text { Non Responders (group I) } \\
\text { No }=20\end{array}$ & P-value \\
\hline ALT U/L & $21.6 \pm 2.7$ & $88.9 \pm 2.2$ & $<0.001^{*}$ \\
\hline AST U/L & $29.1 \pm 2.6$ & $81.2 \pm 2.7$ & $<0.001^{*}$ \\
\hline SOD U/gm Hb & $1999 \pm 3.4$ & $1105.1 \pm 2.3$ & $<0.001 *$ \\
\hline MDA nmol / mL & $6.9 \pm 0.8$ & $11.5 \pm 1.9$ & $<0.001^{*}$ \\
\hline IL10 pg/mL & $33.4 \pm 2.5$ & $43.6 \pm 3$ & $<0.001^{*}$ \\
\hline
\end{tabular}

* highly significant

Table (11): Comparison between the control (group III) and responders (group II) before treatment as regarding laboratory data.

\begin{tabular}{|c|c|c|c|}
\hline & $\begin{array}{c}\text { Control (group III) } \\
\text { No }=20\end{array}$ & $\begin{array}{c}\text { Responders (group II) } \\
\text { No }=\mathbf{2 0}\end{array}$ & P-value \\
\hline ALT U/L & $21.6 \pm 2.7$ & $89.8 \pm 2.8$ & $<0.001 *$ \\
\hline AST U/L & $29.1 \pm 2.6$ & $83.3 \pm 3.8$ & $<0.001 *$ \\
\hline SOD U/gm Hb & $1999 \pm 3.4$ & $1109.2 \pm 2.6$ & $<0.001 *$ \\
\hline MDA nmol / mL & $6.9 \pm 0.8$ & $11 \pm 1.9$ & $<0.001 *$ \\
\hline IL10 pg/mL & $33.4 \pm 2.5$ & $42.9 \pm 3.4$ & $<0.001 *$ \\
\hline
\end{tabular}

* highly significant

Table (12): Comparison between the control (group III) and non responders (group I) before treatment as regarding laboratory data.

\begin{tabular}{|c|c|c|c|}
\hline & $\begin{array}{c}\text { Control (group III) } \\
\text { No }=20\end{array}$ & $\begin{array}{c}\text { Non Responders (group I) } \\
\text { No }=\mathbf{2 0}\end{array}$ & P-value \\
\hline ALT U/L & $21.6 \pm 2.7$ & $91.8 \pm 3.6$ & $<0.001^{*}$ \\
\hline AST U/L & $29.1 \pm 2.6$ & $82.1 \pm 3.2$ & $<0.001^{*}$ \\
\hline $\mathrm{SOD} \mathrm{U/gm} \mathrm{Hb}$ & $1999 \pm 3.4$ & $1108.3 \pm 2.8$ & $<0.001^{*}$ \\
\hline MDA nmol / mL & $6.9 \pm 0.8$ & $11.7 \pm 2.6$ & $<0.001^{*}$ \\
\hline IL10 pg/mL & $33.4 \pm 2.5$ & $44.9 \pm 3.6$ & $<0.001 *$ \\
\hline
\end{tabular}

* highly significant

Kafrelsheikh Vet. Med. J. Vol. 12 No. 2 (2014) 


\section{DISCUSSION}

The hepatitis $\mathrm{C}$ virus (HCV) is widely distributed and causes serious liver disease. Patients with acute hepatitis $\mathrm{C}$ leading to chronic state develop cirrhosis that finally may transform into hepatocellular carcinoma (Yenen, 1996).

ROS plays a crucial role in the induction and progression of liver disease, and are involved in the transcription and activation of a large series of cytokines that could induce production of ROS (Fisher and Naughton ., 2003).

The presence of significant increase in MDA levels also indicates a possible oxidative insult in these patients. The levels of MDA have been correlated with the severity of chronic hepatitis (Cunningham et al ., 2002).

Several host mechanisms are in place to neutralize the harmful effect of free radicals; these include a system of nutritional and endogenous enzymatic antioxidant defences that generally restrain the production of free radicals and prevent oxidative stress and subsequent tissue damage (Balasubramanian and Kowdley, 2005).

Enzymatic antioxidant defense of the organism includes: SOD, CAT, and GSH-Px. Superoxide dismutase protects a cell from toxic effect of superoxide radicals as it catalyzes the dismutation reaction of the radicals (Boya et al ., 1999).

In the current study, MDA was increased in $\mathrm{CHC}$ patients compared to normal controls. Lebensztein 1995 reported elevated MDA levels in children with chronic hepatitis B. 
Our results showed that SOD in non responder group before treatment was $1108.3 \pm 2.8 \mathrm{U} / \mathrm{gm} \mathrm{Hb}$ and after treatment was $1105.1 \pm$ $2.3 \mathrm{U} / \mathrm{gm} \mathrm{Hb}$ with $\mathrm{P}$ value 0.2 in which there is no significant change in its value, this result agree with Boya $\boldsymbol{P}$ et al ., 1999 that show MDA is reflection of lipid peroxidation and SOD is an important antioxidant defence enzyme that converts superoxide into hydrogen peroxide. Increased SOD activity appears to be an adaptive response to increased generation of the superoxide ions.

Higueras et al, 1994 also demonstrated significantly lower mean value of serum MDA levels after the interferon treatment compared with the pre-treatment levels. The results presented confirm the value of MDA as laboratory test in liver diseases and as a useful tool for observing the pathogenic and the therapeutic mechanism of this viral infection.

Chrobot et al, 2000 demonstrated that SOD and catalase levels decreased in children infected with chronic hepatitis $\mathrm{C}$ and $\mathrm{B}$. On the same aspectra Yasuyama et al 1988 showed decrease level of SOD in liver tissue of patients with acute, and chronic hepatitis accompanied by fatty degeneration while comparing with patients with the liver inflammatory diseases of different etiology.

Our present study showed a high significant increase in SOD in responder group before treatment was $1109.2 \pm 2.6 \mathrm{U} / \mathrm{gm} \mathrm{Hb}$ and after treatment was $1992.9 \pm 3.2 \mathrm{U} / \mathrm{gm} \mathrm{Hb}$ at $\mathrm{P}$ value $<0.001$, also SOD in non responder group before treatment was $1108.3 \pm 2.8 \mathrm{U} / \mathrm{gm} \mathrm{Hb}$ and after treatment was $1105.1 \pm 2.3 \mathrm{U} / \mathrm{gm} \mathrm{Hb}$ with $\mathrm{P}$ value 0.2 in which there is no significant change in its value. 
Several clinical trials have previously suggested a beneficial effect of antioxidants in patients with chronic HCV infections. The results of the study by Melhem et al 2005 suggest that antioxidative treatment using a combination of multiple antioxidants in patients with chronic $\mathrm{HCV}$ infections, may ameliorate the inflammatory response as measured by liver enzymes and liver biopsy inflammatory score.

The present study illustrated that IL-10 in responder group before treatment was $42.9 \pm 3.4 \mathrm{pg} / \mathrm{mL}$ and show high significant decrease after treatment to become $36.7 \pm 2.8 \mathrm{pg} / \mathrm{mL}$ at $\mathrm{P}$ value $<0.001$ and in non responder group IL-10 before treatment was $44.9 \pm 3.6 \mathrm{pg} / \mathrm{mL}$ and after treatment was $43.6 \pm 3 \mathrm{pg} / \mathrm{mL}$ with $\mathrm{P}$ value 0.1 in which there is no significant change in its value.

It has been reported that patients with chronic $\mathrm{HCV}$ infections show increase serum IL-10 concentration (Marín et al 2006).

Jia et al 2002 reported that treatment with IFN-alpha for 12 weeks decreased the levels of IL- 10. This significant decrease of IL-10 after interferon administration might be explained by the fact that HCV was cleared by interferon through immunomodulation in addition to direct antiviral activity.

\section{CONCLUSION}

The present study demonstrates that in chronic hepatitis $\mathrm{C}$ patients serum IL-10 level is high with no significant reduction in serum IL-10 level post treatment in non responders, but there is a highly significant reduction in IL-10 level post treatment in responders so we concluded that there is a relation between serum IL-10 level and response to 
pegylated interferon and rebavirin combination therapy in chronic $\mathrm{HCV}$ patients. Also the present study demonstrates the lower pre-treatment level of antioxidant enzyme SOD and higher pre-treatment level of MDA might be probable markers of the oxidative stress. Reversal change of these levels with completion of the treatment in responders group may indicate a correlation between the oxidative stress and the viral pathogenesis. Antioxidant supplement can be added in these patients during their clinical survey. However, further investigations to highlight this issues are recommended.

\section{REFERENCES}

- Appel N, Zayas M, Miller S, Krijnse-Locker J, Schaller T, Friebe P, Kallis S,Engel U, and Bartenschlager $R$ (2008): Essential role of domain III of nonstructural protein $5 \mathrm{~A}$ for hepatitis $\mathrm{C}$ virus infectious particle assembly". PLoS Pathog ; 4: 1035.

- Andrzejak R, Goch JH, and Jurga M (1995): A free radical mechanism for inhibition of arteriosclerosis development with calcium antagonists. Post Hig Med Doæw; 49(4): 531-549.

- Balasubramanian S, and Kowdley KV (2005): Effect of alcohol on viral hepatitis and other forms of liver dysfunction. Clinics in liver disease; 9(1):83-101.

- Boya P, Pena A, Beloqui O, Larrea E, Conchillo M, and Castelruiz Y. (1999): Antioxidant status and glutathione metabolism in peripheral blood mononuclear cells from patients with chronic hepatitis C. J Hepatol 1999; 31:808-814. 
- Brooks DG, Trifilo MJ, Edelmann KH, Teyton L, and Oldstone MB (2006): "Interleukin-10 determines viral clearance or persistence in vivo. Nat Med; 12:1301-9.

- Chrobot AM, Szaflarska S. and Drewa G (2000): Antioxidant defense in children with chronic viral hepatitis B and C". Med Sci Monit ; 6:713-718.

- Couper KN, Blount DG, Riley EM. IL-10 (2008): The master regulator of immunity to infection". J Immunol; 180:5771-7.

- Cunningham-R, Ahrn S, Abuav-Nussbaum R, and Dnistrian A (2002): Development of immunocompetence: Role of micronutrients and microorganisms. Nutr Rev; 60: S68-S72

- De Waal-Malefyt $R$ et al. Interleukin 10.: Current Opinion in Immunology 4: 314-20 (1992)

- Fiorentino DF et al.: IL10 inhibits cytokine production by activated macrophages. Journal of Immunology 147: 3815-22 (1991)

- Fisher AE, and Naughton DP (2003): Vitamin C contributes to inflammation via radical generating mechanisms: a cautionary note". Med Hypotheses ; 61: 657-660.

- Guerra A, and Ann(2001): Studying the relationship between oxidative stress malondialdehyde and $\beta$-carotene in the serum of asthmatic patients in Basrah Governorate-Iraq Med. Intrna., 18 (6), 326. 
- Higueras V, Raya A, Rodrigo JM, Serra MA, and Roma J. (1994): Interferon decreases serum lipid peroxidation products of hepatitis $\mathrm{C}$ patients". Free Radic Biol Med ;16:131-133.

- H. A. Boushey, M. J. Holtzman and J. R. Shelan(1980): Am, Rev. Respir. Dis., 121, 289.

- Hsu DH et al.: Expression of IL10 activity by Epstein-Barr virus protein BCRFI. Science 250: 830-2 (1990)

- Inglot M, Gładysz A, Rymer W, Molin I, Zalewska M, Machaj A (2008): " Cytokine assessment in untreated hepatitis $C$ virus infected patients and during interferon alpha + ribavirine therapy". Wiad Lek; 61:13-8.

- Jia HY, Du J, Zhu SH, Ma YJ, Chen HY, and Yang BS. (2002): The roles of serum IL-18, IL-10, TNF-alpha in patients with chronic hepatitis C". Hepatobiliary Pancreat Dis. Int., 1 (3), 378-82.

- Kamanaka M, Kim ST, Wan YY, Sutterwala FS, and Galán (2006): Expression of interleukin-10 in intestinal lymphocytes detected by an interleukin-10 reporter knockin tiger mouse. Immunity; 25:941-52.

- Kreft B et al (1992): Detection of intracellular interleukin-10 by flow cytometry Journal of Immunological Methods156: 125-8.

- Howard M and O'Garra A. (1992): "Biological properties of interleukin 10". Immunology Today 13: 198-200. 
- Larrea E, Beloqui O, Munos-Navas MA, Civeira MP, Prieto J (1998): "Superoxide dismutase in patients with chronic hepatitis C virus infection". Free Radic Biol Med; 24:1235-1241.

- Lebensztejn DM (1995): The role of free oxygen radicals in children with chronic viral hepatitis B". Roczniki Akademii Medycznej Bialymstoku ;40(3):667-72.

- Levent G, Ali A, Ahmet A, Can Polat E, Ayta C, Ayse E, et al (2006): "Oxidative stress and antioxidant defense in patients with chronic hepatitis $\mathrm{C}$ patients before and after pegylated interferon alfa-2b plus ribavirin therapy". J Transl Med; 4:25-32.

- Marín S, Rodríguez R, Díaz F, Martín H, and Girón G (2006): Modulation of the anti-inflammatory interleukin 10 and of proapoptotic IL-18 in patients with chronic hepatitis $\mathrm{C}$ treated with interferon alpha and ribavirin. J. Viral. Hepat; 13 (4), 230-4.

- Melhem A, Stern M, Shibolet O, Israeli E, Ackerman Z, and Pappo $\boldsymbol{O}$, (2005): Treatment of chronic hepatitis $\mathrm{C}$ virus infection via antioxidants: results of a phase I clinical trial". J Clin Gastroenterol; 39:737-742.

- Muriel P (2009): Role of free redicals in liver diseases. Hepatol Int, 3: $526-36$

- Nishikimi, M., Roa, N.A., and Yogi, K (1972): Biochem. Bioph. Res. Common., 46, $849-854$. 
- Ohkawa, H., Ohishi W, and Yagi K (1979): Anal. Biochem ;95, 351.

- Parola M, and Robino G (2001): Oxidative stress-related molecules and liver fibrosis. J Hepatol; 35:297-306.

- Paradis V, Mathurin P, Kollinger M, Imbert-Bismut F, Charlotte F, Piton A, et al (1997): "In situ detection of lipid peroxidation in chronic hepatitis C:correlation with pathological features". J Clin Pathol; 50:401-406.

- Reitman, S., and Frankel, S., Amer. J (1957): Clin. Path ;28:56.

- Simmonds P (2004): Genetic diversity and evolution of hepatitis C virus-15 years on. J Gen Virol ; 85:3173-3188.

- Schmidt, E., and Schmidt, F.W. (1963): Enzyme. Biol. Clin. 3:1.

- Snell NJ. (2001): Ribavirin current status of a broad spectrum antiviral agent. Expert Opin Pharmacother.;2(8):1317-24

- Swan, T (2006): Care and Treatment for Hepatitis C and HIV Coinfection. U.S. Department of Health and Human Services, Health Resources and Services Administration, HIV/AIDS Bureau, April.

- T. Fouad (2005): http: www. The doctors loung. net.

- Yasuyama T, Inoue K, Kojima T, and Sasaki H (1988): Activities, electrophoretic profiles and immunolocalization of superoxide dismutase in human liver specimens. Jpn J Med; 27: 34-41

- Yenen OS (1996): Viral Hepatitis. Infectious Diseases (Eds. A. Wilke Top• u, G. S.yletir, M. DoÛanay) Nobel Medicine Bookstore, Üstanbul 1: 700-760 
در اسة مستوى الانترليوكين -10 لاى المرضى المصابين بفيروس سى و يتم علاجهم بالانترفيرون و الريبافيرين

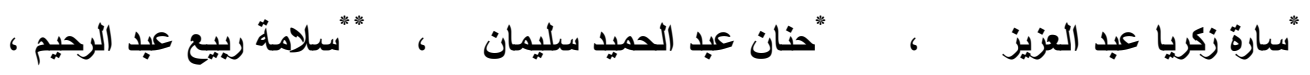

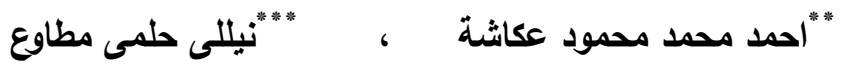

$$
\begin{aligned}
& \text { " قسم الكيمياء- كلية الطوم- جامعة بنى سويف } \\
& \text { " قسم الكيمياء الحيوية - كلية الطب- جامعة المنيا } \\
& \text { • • قسم الباطنة- كلية الطب- جامعة المنيا }
\end{aligned}
$$

إن عدوى الالتهاب الكبدي الوبائي الفيروسي- سي سبب رئيسي لمرض الكبد المزمن بالعالم؛ أكثر من نصف المرضى في الحالات الحادة تستمر فيهم العدوى لتكون مزمنة و التي تؤدى لتليف كبدي أو أورام بالخلايا الكبدية في 20\% من الحالات ـ العلاج بالانترفيرون يقلل الإصابة بفيروس سي لمستوى كبير و يحسن فرص الثفاء. السبب الأساسي للعلاج بمضادات الفيروس في هؤلاء المرضى هو مقاومة العدوى و التي يعبر عنها بعد انتهاء العلاج ب 24 أسبوع .HCV-RNA وعلى الرغم من التقدم في تلك المجال فإن حوالي 50\% من المرضى لا يحققا مقاومة العدوى بالعلاج المضاد للفيروس.

ولقد صممت هذه الدراسة لفحص و تقييم العلاقة بين معدل الانترليوكين-10فى السيرم ومستوى ، الإنزيم الدضادة للأكسدة السوبر اوكسيد ديز ميوتاز ومالون داي الدهيد والاستجابة للانترفيرون ألفا (2أ) و الريبافيرين لعلاج الالتهاب الكبدي المزمن لفيروس سي. تتضمن هذه الدراسة 60 مريض مصابين بفيروس سي تتراوح أعمارهم بين 40-60 سنة كلهم

$$
\text { من الذكور • وقد قسمت المجموعات كالتالي: }
$$

المجموعة الأولي: 20 مريض مصابين بفيروس سي ويتم علاجه بواسطة الإنترفيرون والريبافيرين ولكنهم لم يستجيبوا إلي العلاج وتوقفوا عن العلاج بعد 12 أسبوع وذلك بعد عمل 


$$
\text { بي سي أر (موجب بالفيروس). }
$$

المجموعة الثانية: 20 مريض مصابين بفيروس سي (اجسام مضادة لفيروس سى) ويتم علاجهم بواسطة الإنترفيرون والريبافيرين واستجابوا إلي العلاج بعد فترة تتراوح بين 24-48

$$
\text { أسبوع وذلك بعد عمل بي سي أر (سالب بالفيروس). }
$$

المجموعة الثالثة (المجموعة الضابضة): 20 من الأشخاص الطبيعيين غير مصابين بفيروس سي

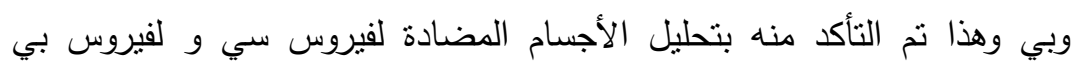

$$
\text { (سالب للجسم المضاد). }
$$

المرضي الذين تم اختيارهم تلقوا العلاج المختلط من الإنترفيرون والريبافيرين بحيث ياخذ

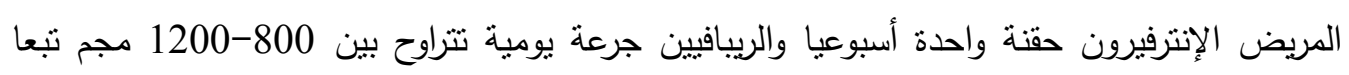

$$
\text { لوزن المريض >75 كجم } 1000 \text { مجم - >75 كجم } 1200 \text { مجم. }
$$

وقد اوضحت النتائج أن في المجموعة الأولى الغير مستجيبة للعلاج انه مازال معدل الانترليوكين-10 في السيرم مرتفع و كذلك مستوى المالون داي الدهيد بينما الانزيم المضاد للأكسدة السوبر اوكسيد ديز ميو ناز مازال منخفض.

بينما في المجموعة الثانية المستجيبة للعلاج بالانترفيرون الفا2أ و الريبافيرين معدل الانترليوكين-10 والمالون داي الدهيد انخفض ومستوى الإنزيم المضاد للأكسدة السوبر اوكسيد ديز

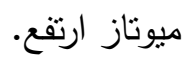

ومن ذلك نستتج أن المصابين بفيروس سي يكونون تحت تأثير ضغط الأكسدة حيث تزيد لديهم معدلات مالون داي ألدهيد ويقل معدل الانزيم المضاد للأكسدة سوبراوكسيد ديزميوناز وبعد العلاج بواسطة الإنترفيرون والريبافيرين تقل معدلات مالونيل الألدهيد ويزيد معدل الانزيم المضاد للأكسدة

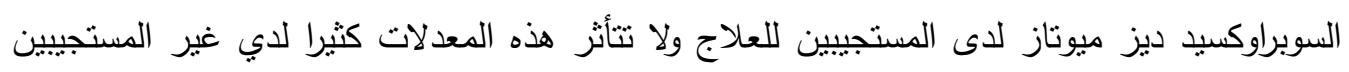
للعلاج. وبذلك يمكن أن نستتنج أنه توجد علاقة قوية بين الإصابة بفيروس الالتهاب الكبدي سي ومستوى الانترليوكين-10 في السيرم و نقص الانزيمات المضاد للأكسدة. 
ولذلك نوصى بعمل المزيد من الأبحاث حول الإنترلوكين-10. 